\title{
Stakeholders' Perception and Preferences of Post-harvest Quality Traits of Tomato in Ghana
}

\author{
Michael K. Osei ${ }^{1,2}$, Agyemang Danquah ${ }^{2}$, Essie Blay ${ }^{2}$, Eric Danquah $^{2} \&$ Hans Adu-Dapaah $^{1}$ \\ ${ }^{1}$ CSIR-Crops Research Institute, P.O.BOX 3785, Kumasi, Ghana \\ ${ }^{2}$ University of Ghana, West Africa Centre for Crop Improvement, Legon, Ghana \\ Correspondence: Michael K. Osei, CSIR-Crops Research Institute, P.O.BOX 3785, Kumasi, Ghana. E-mail: \\ oranigh@hotmail.com
}

Received: February 21, 2018 Accepted: March 16, 2018 Online Published: July 10, 2018

doi:10.5539/sar.v7n3p93

URL: https://doi.org/10.5539/sar.v7n3p93

\begin{abstract}
The high levels of tomato consumption coupled with wide production levels in Ghana make the crop economically viable. Food preferences vary among individuals and geographical locations. Traits to select during crop improvement therefore, depend on the target beneficiaries. Breeders sometimes fail to consider preferences of end users probably because they are oblivious of them. This study used Participatory Rural Appraisal (PRA) and surveys to identify preferences and perceptions of end users in tomato value chain, for making proper breeding choices according to the information collected. The strategy employed for this research was descriptive survey. The target population included tomato farmers, market players and consumers. A multi-stage sampling was used to select the study sample. More than half (57.3\%) of the respondents had been involved in tomato production for over 10 years. Sixteen variables were discussed with each group. The first three principal components (PCs) with Eigen values greater than 1.0 together explained 100\% of total variation in the data set. Scores for ranking popular vegetable and ranking causes for poor shelf life were not significantly associated with any of the components. The Focus Group Discussion (FGDs) also established that, seven main vegetable crops were cultivated and produced by the communities and ranked tomato as number one. Similarly, six important quality traits of tomato were mentioned by stakeholders as their favorite. Respondents showed extreme preferences for firmness and shelf life as the most important quality traits of tomato. Seventy-seven-point five percent $(77.5 \%)$ of the consumers use tomatoes every day in their food preparation. The study revealed stakeholders' desire and plea for firmness and extended shelf life of tomato fruits in Ghana. Consequently, the survey validated the need to regulate tomato breeding goals to develop high yielding tomatoes with improved fruit quality and prolonged shelf life.
\end{abstract}

Keywords: tomato, post-harvest traits, PRA, FGD, descriptive study

\section{Introduction}

The high levels of tomato consumption coupled with wide production levels in Ghana make the sector appear economically viable. Consumption of tomato however, exceeds production in Ghana. In recent years, Ghana has been cited as the second largest consumer of tomato paste in the world. According to the Ghana National Tomato Producers' Federation, Ghana produces 510,000 metric tons $(t)$ of tomato each year, while it imports up to 7,000 $\mathrm{t}$ per month from its neighbors, along with 27,000 t of processed tomato from Europe (Inusah et al., 2013). Tomato production serves as a source of income for most rural and peri-urban producers in Ghana. Despite these, many challenges are beset its production making it not very lucrative in Ghana. The challenges faced by producers and other stakeholders are in production, post-harvest, marketing or a combination of any of them. In addition, regional trade agreement policies have opened a market opportunity in Ghana for tomato farmers from Burkina Faso, presenting further challenges for local farmers. It is now an annual habitual usually between March and May for the tomato "market queens" to travel all the way to neighboring Burkina Faso to purchase tomatoes, encountering several hazards on the highways. According to Inusah et al. (2013) the tomato from Burkina Faso are of higher quality and sell more quickly than local varieties. They emphasized that "Burkina tomatoes are bigger, harder and superior in taste and last longer in storage". Combinations of the above factors created a restricted market monopolized by these so called 'market queens'. Their activities are facilitated by service providers who play various exploitative roles to the disadvantage of small-scale farmers in Ghana. It 
must be noted however, that food preferences may vary among individual age groups, gender and sometimes cultures as well as geographical locations (Sugri et al., 2012). Traits to select during crop improvement therefore, depend on the target beneficiaries (Sugri et al., 2012). Even though emphasis in crop research is increasingly shifting from quantity to quality of production in recent times (Oko-Ibom \& Asiegbu, 2007), there is still little improvement in the quality of commercially produced tomato varieties (Beckles, 2012), hence resulting in high amount of qualitative losses. However, qualitative loss in tomato production can have a negative impact on many parameters like consumer acceptability, nutrient status of fruits, and financial income to producers. An investigation into the possible factors that can affect the postharvest quality of tomatoes is therefore necessary. It is believed that some cultivars that have been released were not espoused because of lack of adequate consideration of farmers' (Derera et al., 2006), and other stakeholders' preferences in the process of their development. Breeders failed to consider the special preferences of farmers (Toomey, 1999; Banziger \& Cooper, 2001), probably because they are oblivious of them (Derera et al., 2006). Breeding programmes must determine their breeding objectives and selection procedures to meet client needs. Effective breeding should be established on clear identification of stakeholders taking into consideration the constraints and preferences. These can be addressed through participatory plant breeding (PPB), participatory varietal selection (PVS) (Gibson et al., 2007; Gasura et al., 2008) and/or participatory rural appraisal. To identify the preferences of end users in the value chain and address them holistically, there is the need to carry out PRA and market surveys to collect the relevant information to make suitable breeding choices. The major objective of the survey was to become acquainted with tomato stakeholders' and ascertain on their varietal preferences, perception, opinions, attitude and knowledge of postharvest quality traits of tomato in Ghana.

\section{Methodology}

\subsection{Description of Study Area}

The study was carried out in nine communities which span in four agro-ecological zones (forest, forest-savannah transition, Guinea savannah, and Sudan savannah). The agroecological zones are found in the Ashanti, Brong Ahafo, Volta and Upper East Regions of Ghana. All the four regions are the major tomato growing areas in the country (Asante et al., 2013). The forest and forest-savannah transition zone have bi-modal rainfall regime of 1300 to $2200 \mathrm{~mm}$ per annum while Guinea and Sudan savannah have a uni-modal rainfall pattern (May to August) with an average of $1100 \mathrm{~mm}$ per annum. Major tomato growing districts and communities within these agro-ecological zones were selected for the survey (Table 1).

Table 1. List of study areas

\begin{tabular}{llll}
\hline Community & District & Region & Agroecological zone \\
\hline Vea & Bongo & Upper East & Sudan savanna \\
Pwalugu & Talensi & Upper East & Sudan savanna \\
Bolgatanga & Bolgatanga & Upper East & Sudan savanna \\
Battor & North Tongu & Volta & Costal savanna \\
Adidome & Central Tongu & Volta & Costal savanna \\
Tuobodom & Techiman North & Brong Ahafo & Transitional \\
Derma & Tano South & Brong Ahafo & Transitional \\
Agogo & Asante Akim & Ashanti & Deciduous forest \\
Akumadan & Offinso North & Ashanti & Deciduous forest \\
\hline
\end{tabular}

\subsection{Research Approach/Strategy}

The strategy of this research is descriptive survey. It was used to determine the suitable quantitative and qualitative data, from a relatively large number of cases with the purpose of providing a systematic description and assessment of the perceptions of stakeholders (Field, 2000; Field, 2005; Kumar, 1999).

\subsection{Study Population and Sample Selection of Respondents}

The target population of the study included tomato farmers, tomato consumers, tomato whole sellers and retailers. These groups of people were targeted because they provided relevant information concerning post-harvest quality traits of tomato in Ghana. A multi-stage sampling procedure was used to select the study sample. The multi-stage sampling procedure was used because the target population structures were large and dispersed across the agro-ecological zones in the country. According to David and Sutton (2004) and Lewin (2005), it is more appropriate to initially select subgroups at various levels rather than randomly selection from the whole population when the population is large and widely dispersed. At the first stage of the multi-stage sampling 
procedure, four agro-ecological zones in four regions were purposively selected from the list of six agro-ecological zones in Ghana. At the second stage, four (4) Districts were purposively selected from the selected four (4) Regions. The districts were purposively selected because they epitomized major tomato production, marketing and utilization areas in Ghana. At the third stage four communities (one of each from the selected district) were again purposively selected from the selected four districts. At the final stage, 157 tomato farmers were randomly chosen from the selected communities to constitute the desired study sample size. The distribution of the respondents by the regions is presented in Table 2 .

One hundred and fifty-seven (157) Farmers, seventy seven (77) market players and forty (40) consumers were also purposively chosen from the selected communities to constitute the desired study sample size.

Table 2. Sample of respondents per region

\begin{tabular}{lllll}
\hline Region & \multicolumn{3}{c}{ Number of Participants } & \multicolumn{2}{c}{ Respondents } \\
\cline { 1 - 4 } & \multicolumn{1}{c}{ Farmers (\%) } & Market players (\%) & Consumers (\%) & \\
\hline Upper East & $51(58.8)$ & $19(27.9)$ & $9(13.2)$ & $79(100)$ \\
Volta & $29(58.8)$ & $18(26.5)$ & $10(14.7)$ & $57(100)$ \\
Ashanti & $38(57.5)$ & $20(27.4)$ & $11(15.1)$ & $69(100)$ \\
Brong Ahafo & $39(55.2)$ & $20(29.9)$ & $10(14.9)$ & $69(100)$ \\
Total & $157(57.5)$ & $77(27.9)$ & $0(14.5)$ & $274(100)$ \\
\hline
\end{tabular}

\subsection{Data Collection}

The study used data from primary and secondary sources. The primary data was collected using Focus Group Discussion (FGD) and semi structured questionnaire. Four FGDs were conducted in four communities (Pwalugu, Adidome, Agogo and Derma) using an interview guide for the interaction (Table 3). Issues of relevance to the topic included in the guide were vegetables types grown, tomato variety grown and important postharvest quality traits of tomato, tomato shelf life and gender. In all 73 participants were involved with an average of 18 participants per community (Table 4). A team of three comprising one facilitator and two recorders led the FGD. In some communities where language was an obstacle, the Agricultural Extension Officer functioned as a translator. The study was conducted between February and March 2017. Observations of importance to the research were noted. The FGDs gave a collective and unanimous opinions on the issues presented.

Table 3. List of study areas for FGD

\begin{tabular}{llll}
\hline Community & District & Region & Agroecological zone \\
\hline Pwalugu & Talensi & Upper East & Sudan savanna \\
Adidome & Central Tongu & Volta & Coastal savanna \\
Agogo & Asante Akim & Ashanti & Deciduous Forest \\
Derma & Tano South & Brong Ahafo & Transitional \\
\hline
\end{tabular}

Table 4. Sample size of FGD

\begin{tabular}{llll}
\hline Community & Males & Females & Total \\
\hline Pwalugu & 12 & 3 & 15 \\
Adidome & 17 & 4 & 21 \\
Agogo & 14 & 1 & 15 \\
Derma & 19 & 3 & 22 \\
Total & 62 & 11 & 73 \\
\hline
\end{tabular}

A semi- structured questionnaire which included personal characteristics, production practice and harvesting, post-harvest including storage, marketing and consumer preference was used to gather data from 274 respondents made up of 157 tomato farmers, 40 tomato consumers, and 77 tomato whole sellers and retailers (Table 2). The designed questionnaire was first pretested in and around Kumasi Metropolis. David and Sutton (2004) recommended that survey questions should be pre-tested on a test group of cases from the target population to ensure its reliability. The survey was conducted between February and March 2017 as a supplement to the Focus Group Discussion (FGD). 


\subsection{Data Analyses}

The summary of various statistical tools used in the analysis based on the objectives of the study is displayed in Table 5 .

Table 5. Summary of statistical tools of data analysis

\begin{tabular}{ll}
\hline Objective & Statistical tools for Analysis \\
\hline $\begin{array}{l}\text { Describe the characteristics of tomato stakeholders } \\
\text { (farmers, consumers, whole sellers and retailers) in } \\
\text { the study areas }\end{array}$ & $\begin{array}{l}\text { Frequencies, percentages, tables, graphs using the } \\
\text { statistical package for social sciences }\end{array}$ \\
\hline $\begin{array}{l}\text { Obj. 1. Examine the role of stakeholders in tomato } \\
\text { production and marketing }\end{array}$ & $\begin{array}{l}\text { The data were converted to numerical values, standardized } \\
\text { (Etzkorn, 2011), and analyzed using Genstat Computer } \\
\text { package (Genstat, 2017). }\end{array}$ \\
\hline $\begin{array}{l}\text { Obj. 2. Assess the production, marketing and } \\
\text { utilization patterns among tomato stakeholders } \\
\text { in the study areas }\end{array}$ & $\begin{array}{l}\text { Frequencies, percentages, tables, graphs using the } \\
\text { statistical package for social sciences (SPSS, 2017). }\end{array}$ \\
\hline
\end{tabular}

\section{Results}

\subsection{Demographic Characteristics of Respondents}

\subsubsection{Group Respondents (Focus Group Discussion)}

Table 6a depicts male dominance of $84 \%$ of the total group respondents engaged in focus group discussion.

Table 6a. Demographic Characteristics of Group Respondents

\begin{tabular}{llll}
\hline Region & Males & Females & Total \\
\hline Upper East & 12 & 3 & 15 \\
Volta & 17 & 4 & 21 \\
Ashanti & 14 & 1 & 15 \\
Brong Ahafo & 19 & 3 & 22 \\
Total & 62 & 11 & 73 \\
\hline
\end{tabular}

Table $6 \mathrm{~b}$ indicates that majority $(74 \%)$ of tomato farmers were in the age group of 30-50 years. More than seventy-eight percent of men also dominate tomato production. Majority $(53.5 \%)$ of the farmer respondents had primary school education with $24.8 \%$ without any formal education. With regards to tomato production experience, more than half $(57.3 \%)$ of the respondents had been involved in tomato production for over 10 years; $6.4 \%$ for 40 years. However $3.2 \%$ of respondents were not sure of the number of years they have cropped tomatoes. The table also show that $98.7 \%$ of market players (wholesalers $(26 \%)$, retailers $(65 \%)$ and market queens $(9 \%)$ were females implying that females dominate the marketing of tomato in the study areas. More than $67 \%$ of the women fall within the age group of 31-50 years. Sixty percent of the respondents were aware of the varieties they sell to their customers. Major clients of the market players include household consumers (48\%), retailers (43\%), restaurants/chop bar operators/food vendors (6\%) and other institutions (3\%). More than half the consumers $(53 \%)$ interviewed fall within the age range of 21-30 years. About forty-eight percent of the consumers were aware of the tomato variety they purchase or consumed being local or exotic. 
Table 6b. Demographic characteristics of individual respondents

\begin{tabular}{|c|c|c|c|c|c|c|}
\hline \multirow{2}{*}{\begin{tabular}{|l|} 
Variables \\
Variables
\end{tabular}} & \multicolumn{2}{|c|}{$\begin{array}{c}\text { Farmers } \\
\mathbf{N}=157\end{array}$} & \multicolumn{2}{|c|}{$\begin{array}{c}\text { Market } \\
\text { Players N=77 } \\
\end{array}$} & \multicolumn{2}{|c|}{$\begin{array}{l}\text { Consumers } \\
\mathrm{N}=40\end{array}$} \\
\hline & Freq & $(\%)$ & Freq & $(\%)$ & Freq & $(\%)$ \\
\hline \multicolumn{7}{|l|}{ Age (years) } \\
\hline Below 20 & - & - & - & - & 4 & 10 \\
\hline $21-30$ & 35 & 23 & 18 & 23 & 21 & 53 \\
\hline $31-40$ & - & - & 26 & 34 & 12 & 30 \\
\hline $41-50$ & 80 & 51 & 26 & 34 & 2 & 5 \\
\hline $51-60$ & 42 & 27 & 5 & 6 & - & - \\
\hline Above 60 & - & - & 2 & 3 & - & - \\
\hline \multicolumn{7}{|l|}{ Gender } \\
\hline Male & 123 & 78.3 & 1.00 & 1.3 & 18 & 45 \\
\hline Female & 34 & 21.7 & 76 & 98.7 & 22 & 55 \\
\hline \multicolumn{7}{|l|}{ Level of Education } \\
\hline No formal education & 39 & 24.8 & 31 & 40 & 3 & 7.5 \\
\hline Primary/JHS/Middle education & 84 & 53.5 & 40 & 52 & 8 & 20 \\
\hline Secondary (SHS/Vocational) education & 27 & 17.2 & 6 & 8 & 24 & 60 \\
\hline Tertiary education & 7 & 4.5 & - & - & 5 & 12.5 \\
\hline \multirow{2}{*}{\multicolumn{7}{|c|}{$\begin{array}{l}\text { Tomato Production/Marketing } \\
\text { Experience (Years) }\end{array}$}} \\
\hline & & & & & & \\
\hline$<5$ & - & - & - & - & - & - \\
\hline $1-10$ & 90 & 57.3 & 36 & 47 & - & - \\
\hline $11-20$ & 40 & 25.5 & 30 & 39 & - & - \\
\hline $21-30$ & 12 & 7.6 & 9 & 11 & - & - \\
\hline $31-40$ & 10 & 6.4 & 2 & 3 & - & - \\
\hline Unknown & 5 & 3.2 & - & - & - & - \\
\hline \multicolumn{7}{|l|}{$\begin{array}{l}\text { Tomato variety cultivated/ } \\
\text { purchased/Consumed/marketed }\end{array}$} \\
\hline Local & 96 & 61.1 & 55 & 71.4 & 19 & 47.5 \\
\hline Exotic & 26 & 16.6 & 15 & 19.5 & 3 & 7.5 \\
\hline Local and exotic & 15 & 9.6 & 5 & 6.5 & 8 & 20 \\
\hline Do not know & 20 & 12.7 & 2 & 2.6 & 10 & 25 \\
\hline \multicolumn{7}{|l|}{ Major Clients } \\
\hline Wholesale & 76 & 48.4 & - & - & - & - \\
\hline Retailers & 31 & 19.7 & 33 & 43 & - & - \\
\hline Consumers/households & 14 & 8.9 & 37 & 48 & - & - \\
\hline Market Queens & 36 & 22.9 & - & - & - & - \\
\hline Restaurants/Chop bars/Food vendors & & - & 5 & 6 & - & - \\
\hline Other institutions & & - & 2 & 3 & - & - \\
\hline
\end{tabular}

\subsection{Role of Stakeholders in Tomato Production and Marketing (Results of FGDs)}

Sixteen variables (questions) were discussed (Table 7) with each group. The first three principal components (PCs) with Eigen values greater than 1.0 together explained $100 \%$ of total variation in the data set (Table 7). Scores for ranking popular vegetable and ranking causes for poor shelf life were not significantly associated with any of the components. Scores on the first two PCs accounted for $91.87 \%$ of the dissimilarity, and were related to all the questions with the exception of vegetables grown, most popular tomato varieties, important preferred quality trait, rank for important quality trait and causes of poor shelf life which were related to PCs 3 and PCs 4 . 
Table 7. Principal Component Analysis x questions used for the Focal Group Discussion

\begin{tabular}{lllll}
\hline Variables & PC1 & PC2 & PC3 & PC4 \\
\hline Vegetables grown & 0.27658 & 0.26683 & -0.19476 & 0.3656 \\
Rank for popular vegetable & 0.00000 & 0.00000 & 0.00000 & 0.00000 \\
Reasons for ranking tomato high & 0.09369 & 0.40769 & -0.26934 & -0.30659 \\
Most popular tomato variety & 0.15408 & 0.24851 & 0.66306 & -0.38020 \\
Reasons for variety popularity & 0.35342 & 0.07036 & -0.07544 & 0.30073 \\
Reasons ranked high & 0.19255 & -0.34874 & -0.28291 & -0.29195 \\
Important preferred quality trait & 0.27352 & -0.27732 & 0.15425 & 0.01366 \\
Rank for important quality trait & 0.27658 & 0.26683 & -0.19476 & 0.27464 \\
Reasons for the preferred trait & 0.34655 & -0.11440 & 0.04357 & -0.04319 \\
Opinion and attitude of quality & 0.34655 & -0.11440 & 0.04357 & -0.00278 \\
Farmers perception of tomato shelf life & -0.34655 & 0.11440 & -0.04357 & 0.00278 \\
Tomato shelf life & -0.12358 & 0.39892 & -0.24507 & -0.05866 \\
Causes of poor shelf life & 0.27658 & 0.26683 & -0.19476 & -0.55461 \\
Rank of causes for poor shelf life & 0.00000 & 0.00000 & 0.00000 & 0.00000 \\
Farmers own way to increase Shelf life & 0.07425 & 0.37879 & 0.44366 & 0.25210 \\
Rank of farmers approach to Increase shelf life & 0.34655 & -0.11440 & 0.04357 & 0.00211 \\
Eigen Values & 7.752 & 5.110 & 1.138 & 0.000 \\
Variance (\%) & 55.3 & 36.50 & 8.13 & 0.00 \\
Cumulative (\%) & 55.37 & 91.87 & 100.00 & 100.00 \\
\hline
\end{tabular}

Values greater than (>) 0.3 is significant

The distribution produced by PCs 1 and 2 is shown in Figure 1. All the regions are distinctly classified into different groups. Ashanti, Upper East, Volta and Brong Ahafo regions separately categorized in groups 1, 2, 3 and 4 respectively.

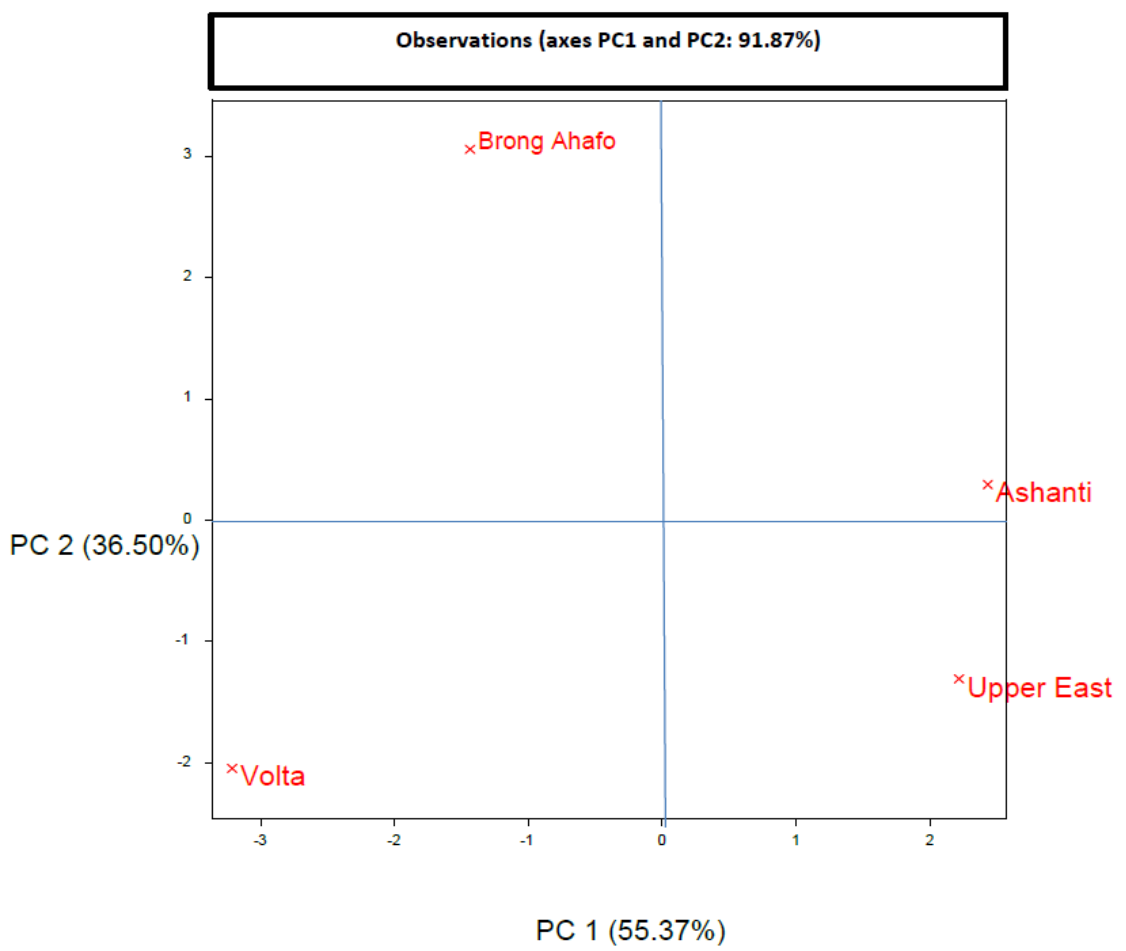

Figure 1. A biplot of PC1 and PC2 showing the distribution of communities involved in the focus group discussion

The hierarchical clustering (Fig. 2) demonstrates the association between responses among the communities. The communities were separated with Euclidean similarity distance from 1.0 to 0.6. Communities in Upper East and Ashanti regions were similar at about 0.85 whereas communities in Brong Ahafo and Volta regions were similar 
at 0.6. However, they were all distinct at 0.83 levels. Two main clusters, A and B were identified at similarity level 0.52. Cluster A was composed of the Upper East and Ashanti Regions, whilst Brong Ahafo and Volta Regions were found in cluster B.

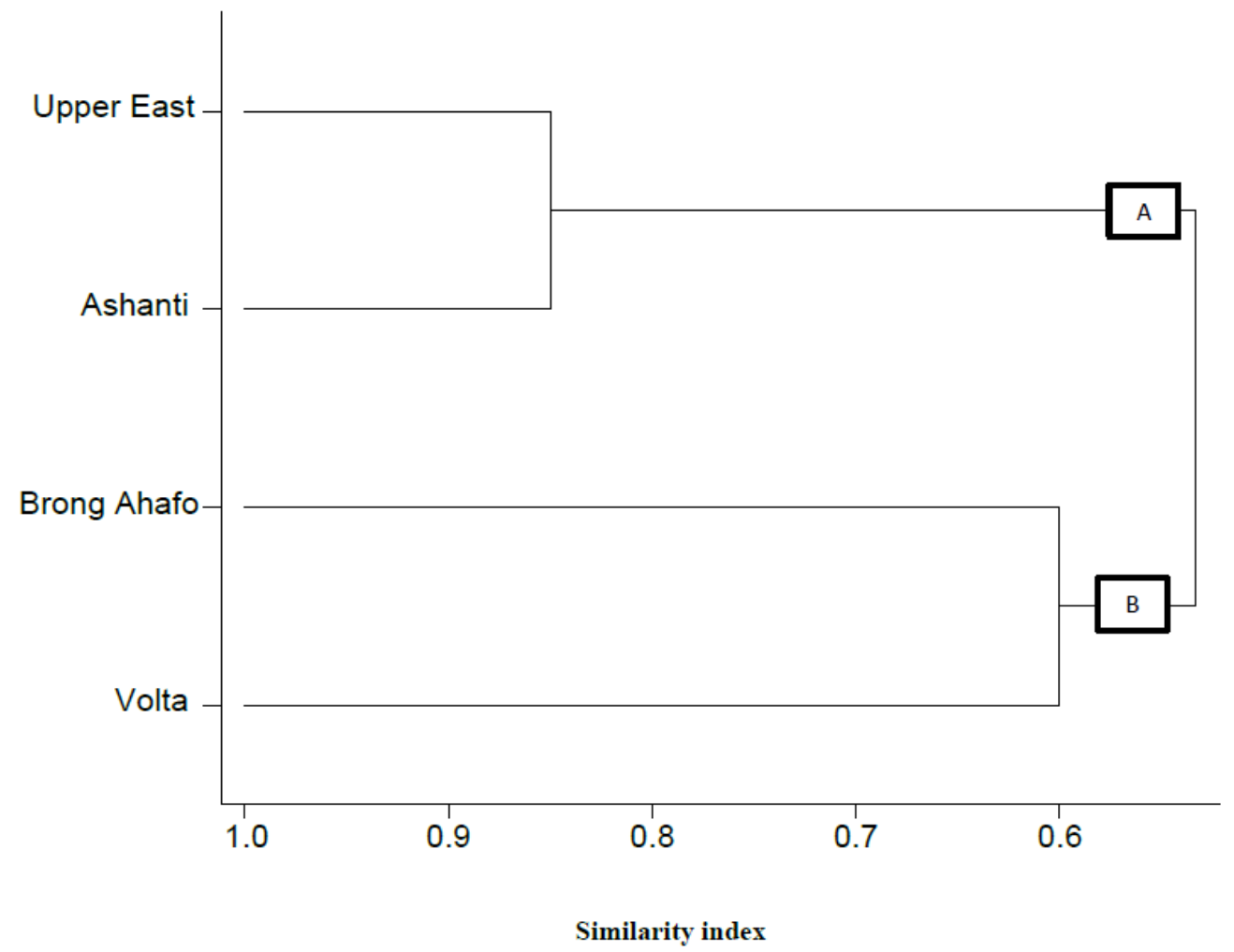

Figure 2. Dendrogram showing response of communities involved in the Focal Group Discussion

\subsection{Vegetable Crop Initiative of the Communities}

The FGDs established that, seven main vegetable crops were cultivated and produced by the communities (Table 8). The range of vegetables cultivated includes tomato, pepper, okra, garden eggs, onion and leafy vegetables. Tomato was ranked first among all the communities.

Table 8. Vegetable crop enterprise ranking within the communities involved in the focus group discussion

\begin{tabular}{lllll}
\hline Rank position & Upper East & Ashanti & Volta & Brong Ahafo \\
\hline $\mathbf{1}$ & Tomato & Tomato & Tomato & Tomato \\
$\mathbf{2}$ & Pepper & Pepper & Okra & Cabbage \\
$\mathbf{3}$ & Leafy vegetables & Cabbage & Pepper & Pepper \\
$\mathbf{4}$ & Onion & Garden egg & Garden egg & Garden egg \\
\hline
\end{tabular}

\subsection{Postharvest Quality Traits of Tomato (Ranking)}

During the FGD, six important quality traits of tomato were mentioned by stakeholders in the various communities as their favorite for any tomato variety (Table 9). They included fruit size, long fruit storage (shelf life), fruit colour, firmness and taste (brix). Ashanti region has the highest preferred quality trait whilst Upper East and Brong Ahafo regions had the least preferred quality traits. Shelf life/long fruit storage and firmness were ranked first in Upper East, Ashanti and Volta, Brong Ahafo regions respectively. The commonest trait across all the communities involved in the focus group discussion was fruit size and fruit colour though they were ranked second and fourth in their respective regions. 
Table 9. Postharvest quality traits of tomato within the communities involved in the focus group discussion

\begin{tabular}{lllll}
\hline Rank position & Upper East & Ashanti & Volta & Brong Ahafo \\
\hline $\mathbf{1}$ & Shelf life/storage & Shelf life/storage & Firmness & Firmness \\
$\mathbf{2}$ & Fruit size & Firmness & Taste & Fruit size \\
$\mathbf{3}$ & Fruit colour & Fruit size & Fruit size & Fruit colour \\
$\mathbf{4}$ & & Fruit colour & Fruit colour & \\
$\mathbf{5}$ & & Taste & & \\
\hline
\end{tabular}

\section{Pattern of Tomato Production, Marketing and Utilization among Tomato Stakeholders}

\subsection{Tomato Production Preferences by Farmers}

\subsubsection{Postharvest Quality Traits of Tomato}

The respondents had fairly uniform and near unanimous perceptions and opinions in their choice of postharvest quality traits of tomato. Respondents across the study areas showed preference for shelf life, firmness, fruit size, fruit colour and taste as an important postharvest quality trait of tomato. They however, showed extreme preferences for firmness and shelf life as the most important quality traits of tomato, and ranked fruit colour and taste as moderate preferences.

\subsection{Farmers' Perception of Tomato Shelf Life and Firmness}

Storage life of tomato fruits

Table 10 indicates the shelf life of tomato fruits as declared by farmers interviewed. They stated different storage life of their tomatoes. More than half (55.3\%) of the respondents can store their tomato fruits for a maximum of six days. Only 5.9\% of the respondents can store their tomato fruits for a maximum of 12 days. When respondents were asked about their satisfaction on the shelf life of their tomato variety, $87.9 \%$ mentioned that they were not pleased with storage period. Respondents who are not pleased with their shelf life of tomato outline several reasons such as reduces quantity and quality of tomato produce, reduces profit and limited life span (Table 11). Farmers on their own employ practice various ways to increase the shelf life of their tomato variety whiles waiting for market. About $30 \%$ of them apply fungicides few days before harvest and or harvest at breaker stage (just before ripen) (Table 12).

Table 10. Storage life of farmers' cultivated varieties

\begin{tabular}{lllll}
\hline Storage period (days) & $1-3$ & $4-6$ & $7-9$ & $10-12$ \\
\hline Percentage of farmers (\%) & 12.5 & 55.3 & 26.3 & 5.9 \\
\hline
\end{tabular}

Table 11. Reasons for displeasure of the storage life of farmer's cultivated varieties

\begin{tabular}{ll}
\hline Reason & Percentage (\%) \\
\hline Reduces quantity and quality of produce (A) & 30.1 \\
Reduces profit (B) & 35.3 \\
Both (A and B) & 33.1 \\
Limited life span & 1.5 \\
Total & 100 \\
\hline
\end{tabular}

Table 12. Temporary measures employed by farmers to lessen poor storage life

\begin{tabular}{ll}
\hline Measures & Percentage (\%) \\
\hline Application of fungicides few days before harvesting & 29.7 \\
Application of calcium on the fruit before harvesting & 2.9 \\
Harvesting at breaker stage (just before ripen) & 29.0 \\
Harvesting at green stage of mature fruits & 10.1 \\
Cover fruits with dry grass & 18.1 \\
Spread fruits on the floor & 10.1 \\
\hline Total & $\mathbf{1 0 0}$ \\
\hline
\end{tabular}




\subsection{Farmers' Perceptions and Opinions about Tomato Shelf Life}

Farmers' views and thoughts about the storage life of tomato fruits are presented in Table 13. They enlisted poor agronomic practices, poor handling of the tomatoes and characteristic nature as their observations and awareness as far as tomato shelf life is concerned. About $71 \%$ of poor shelf life was attributed to the characteristic nature of the tomato variety (genetic) while $8.5 \%$ was pointed to poor handling of the tomatoes. Preponderance of the respondents $(72.5 \%)$ was of the opinion that absence of ready market intensifies the problem of poor shelf life. Others were of the view that improper packaging (13.4\%), precarious transportation (12.7\%) and heavy rainfall (1.4\%) deepen the poor storage life of tomato (Table 14).

Table 13. Respondents perception about poor shelf life of tomato fruits

\begin{tabular}{ll}
\hline Causes of poor shelf life in tomato & Percentage (\%) \\
\hline Poor agronomic practices & 20.6 \\
Poor handling of the harvested tomato & 8.5 \\
Tomato variety (genetic) & 70.9 \\
Total & $\mathbf{1 0 0}$ \\
\hline
\end{tabular}

Table 14. Respondents opinion about poor shelf life of tomato fruits

\begin{tabular}{ll}
\hline Views & Percentage (\%) \\
\hline Lack of ready market & 72.5 \\
Improper packaging & 13.4 \\
Precarious transportation & 12.7 \\
Heavy rainfall & 1.4 \\
Total & $\mathbf{1 0 0}$ \\
\hline
\end{tabular}

\section{Tomato Preferences by Market Players}

\subsection{Market Level Characteristics}

\subsubsection{Criteria of Grading Tomatoes for Sale}

Market players consider number of standards to sell their tomatoes, such as: Fruit size, freshness, ripeness, firmness and colours. Among these benchmarks, firmness of tomato fruit constituted the highest response (38\%) while, fruit colour recorded the least response (3\%) (Figure 3).

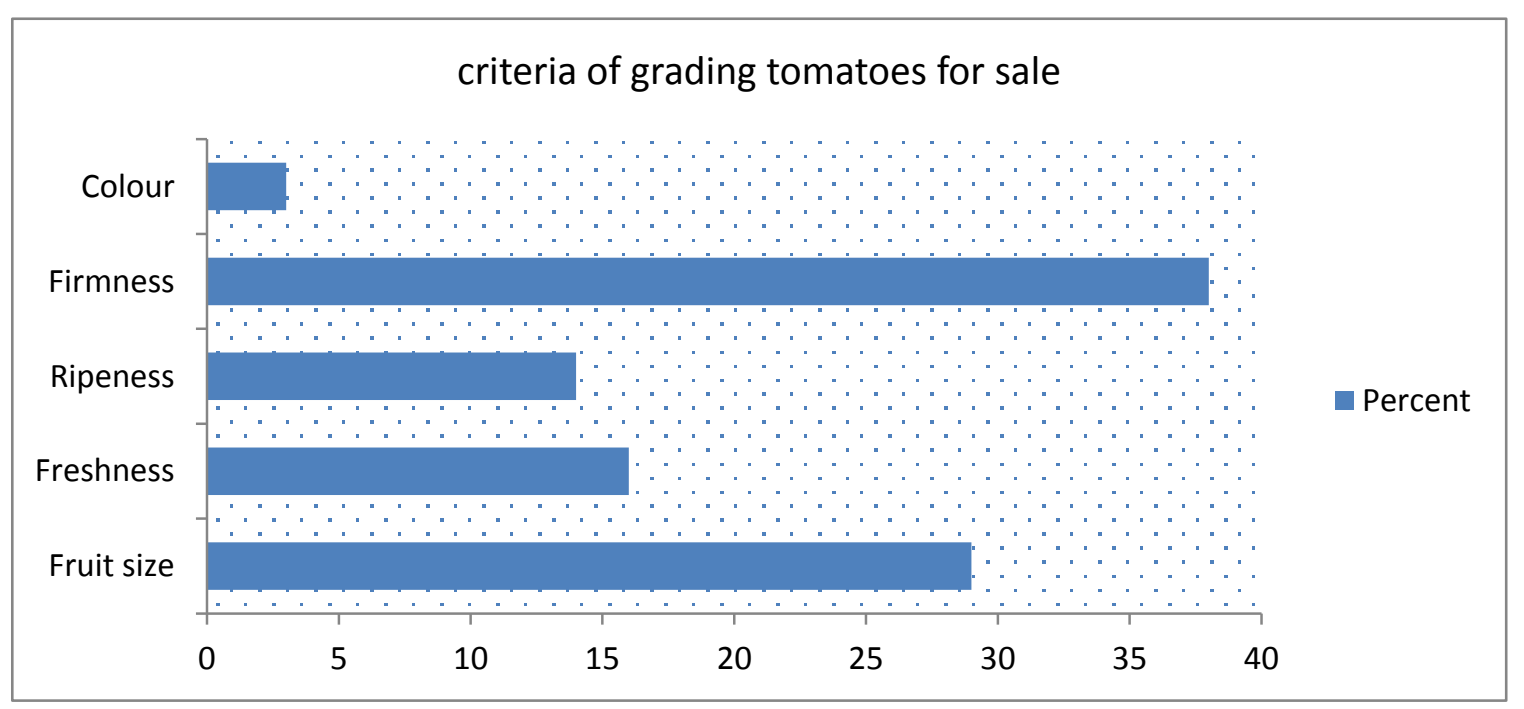

Figure 3. Criteria of grading tomatoes by market players 


\subsection{Market players' Perception and Opinion of Tomato Shelf Life and Firmness}

Fifty respondents representing $65 \%$ indicated that their tomatoes for sale commence deterioration only after 1-3 days. Nonetheless only $3 \%$ of the respondents could keep their tomatoes for 10-12 days before they start to deteriorate. According to the market players especially the retailers, they employ several measures to prolong the shelf life but no avail. Some of these actions include putting tomatoes in a ventilated room (13\%), spreading tomato fruits on the floor (21\%), sorting out and cleaning during marketing (17\%), putting them in a spacious container (19\%), cold store (4\%) and helpless (reduce price and sell out produce) (20\%) (Figure 4).

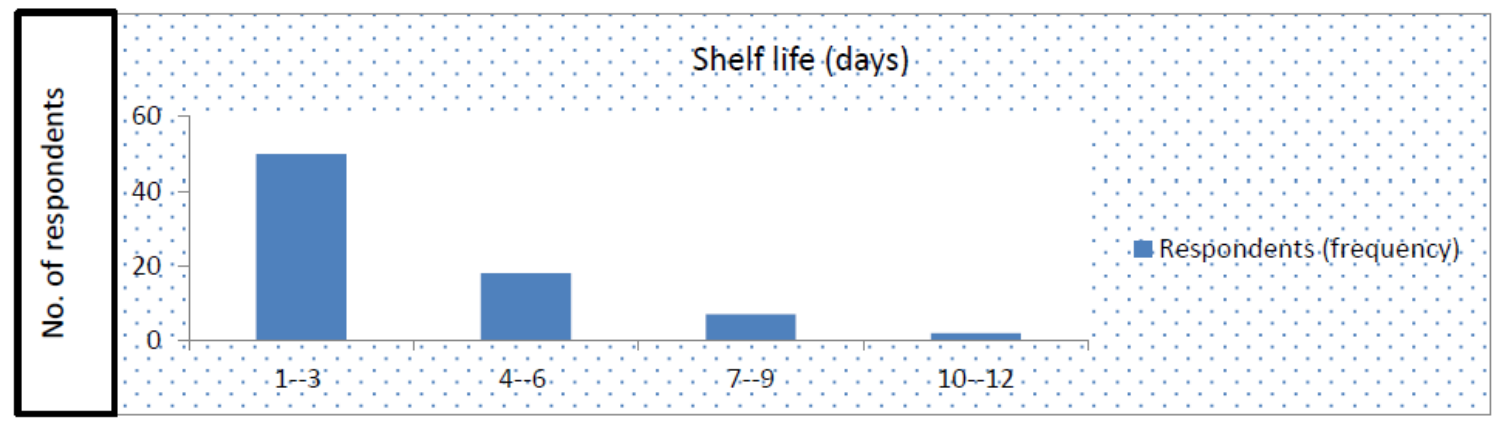

Shelf life (days)

Figure 4. Shelf life of tomatoes as declared by market players

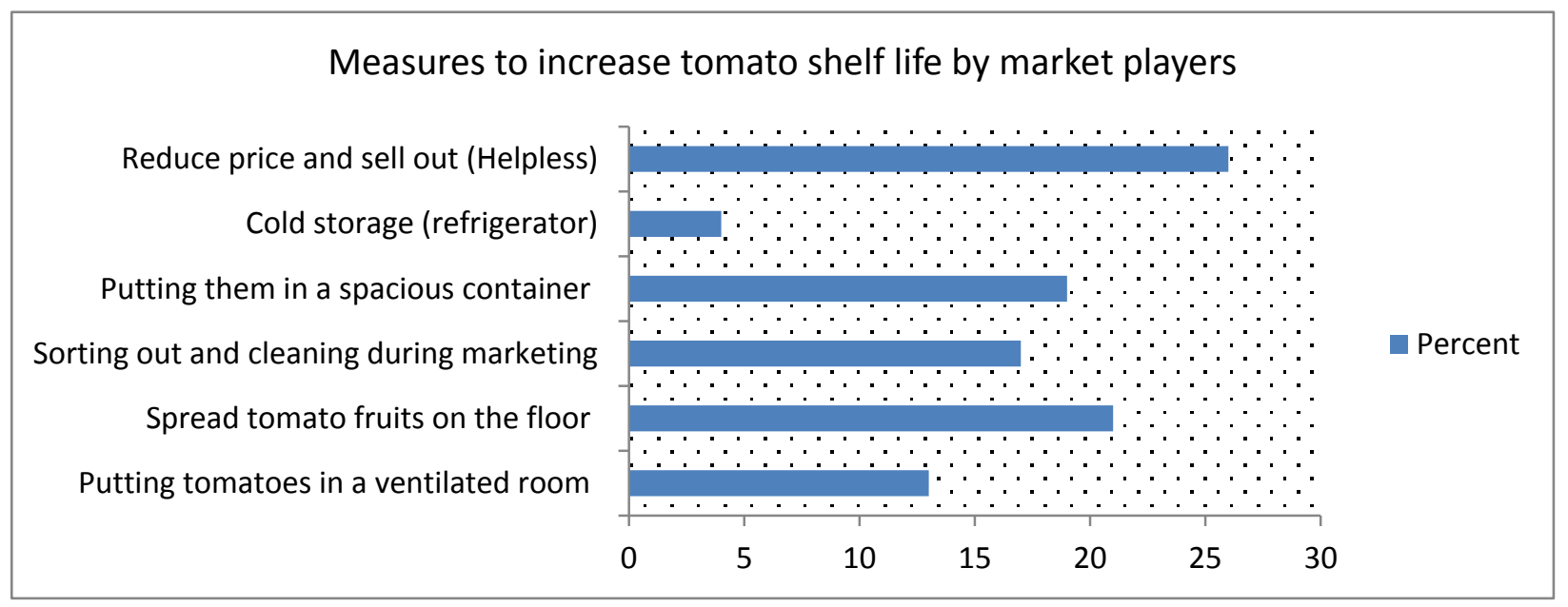

Figure 5. Measures employed by market players to extend shelf life

\subsection{Tomato Utilization and Quality Preferences by Consumers}

\subsubsection{Consumer Level Characteristics}

Tomato consumption pattern is presented in figure 6. Seventy-seven point five percent $(77.5 \%)$ of the consumers use tomatoes every day in their food preparation whilst $10 \%$ and $7.5 \%$ consume twice and thrice a week respectively. Five percent of the respondents were however, not sure of how often they use tomato in their food preparation. Almost all the respondents use tomato in one way or the other. Figure 7 depicts the different forms in which tomatoes are used as mentioned by the respondents. About $93 \%$ of the respondents consume tomato by preparing stew or soup or both (Figure 7). 


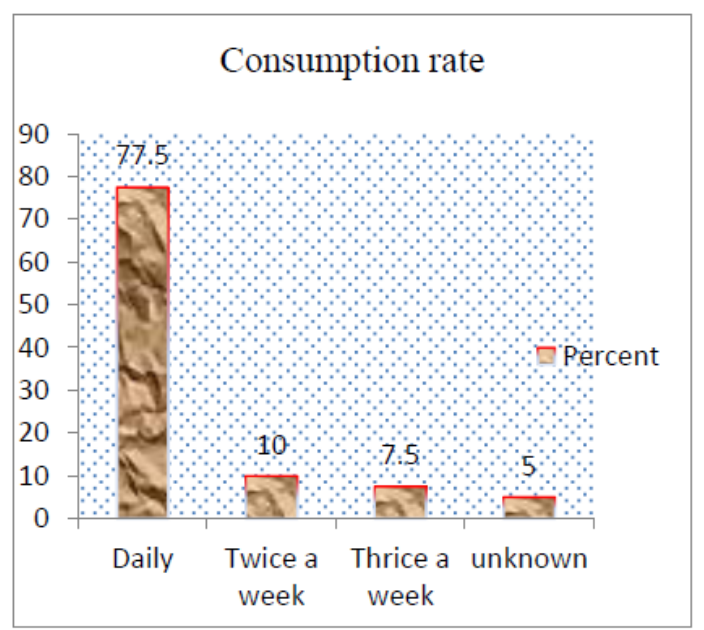

Figure 6. Consumption rate of tomato

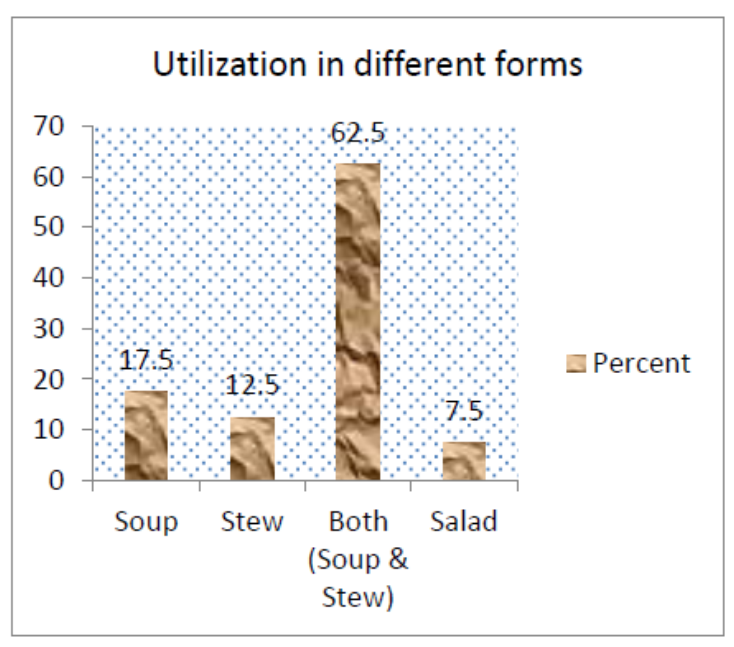

Figure 7. Use of tomato in different forms

The pie chart presents respondents' knowledge of the varieties they purchase from the market. Sixty-two percent of the respondents can identify the tomato variety they purchase (Fig. 8).

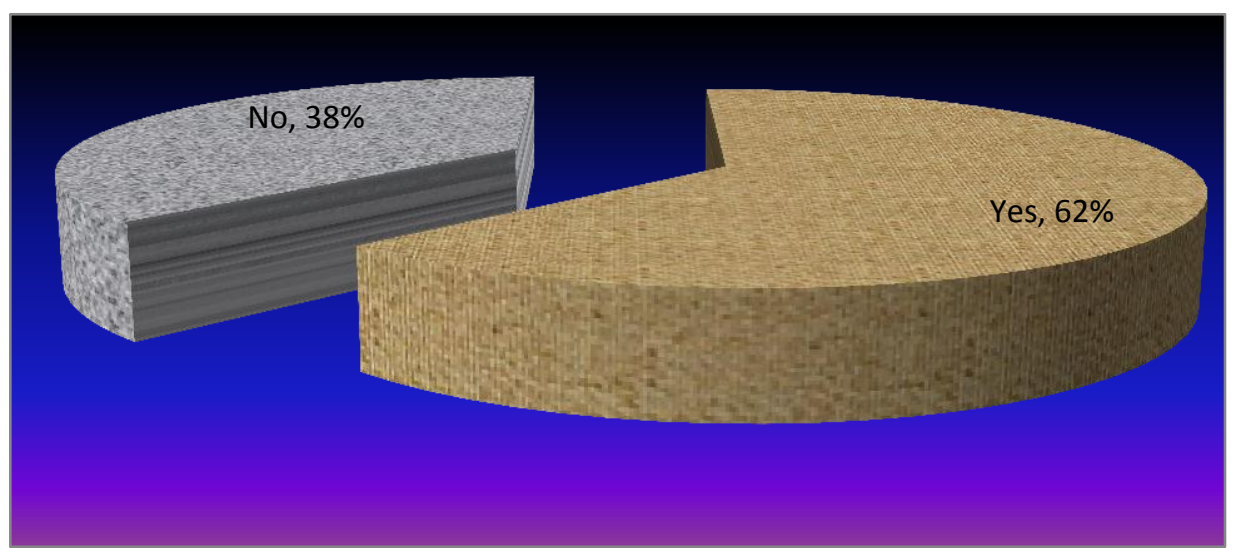

Figure 8. Consumers' knowledge of tomato variety purchased

Quality preference distribution of tomato indicated a response of 50\% and 30\% respondents for firmness and freshness/ripeness respectively (Figure 9). Half of the respondents prefer firmness to fruit size (15\%) and colour $(5 \%)$. Seventy-five percent of the respondents also place high premium on the shelf life and firmness of any tomato purchased for household use, whilst $15 \%$ put premium on the taste of tomato. Only $7.5 \%$ and $2.5 \%$ of the respondents lay premium on big fruit size and fruit shape respectively (Figure 10). 


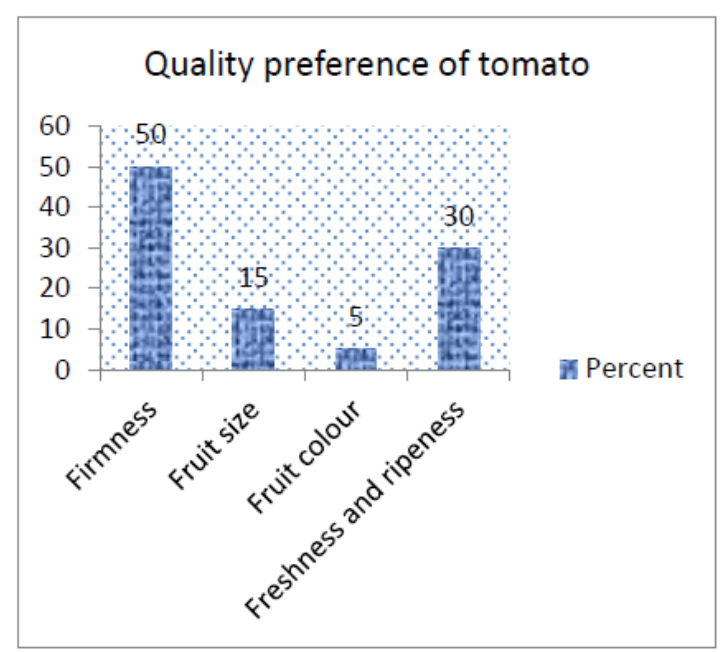

Figure 9 Consumer quality preference in tomato

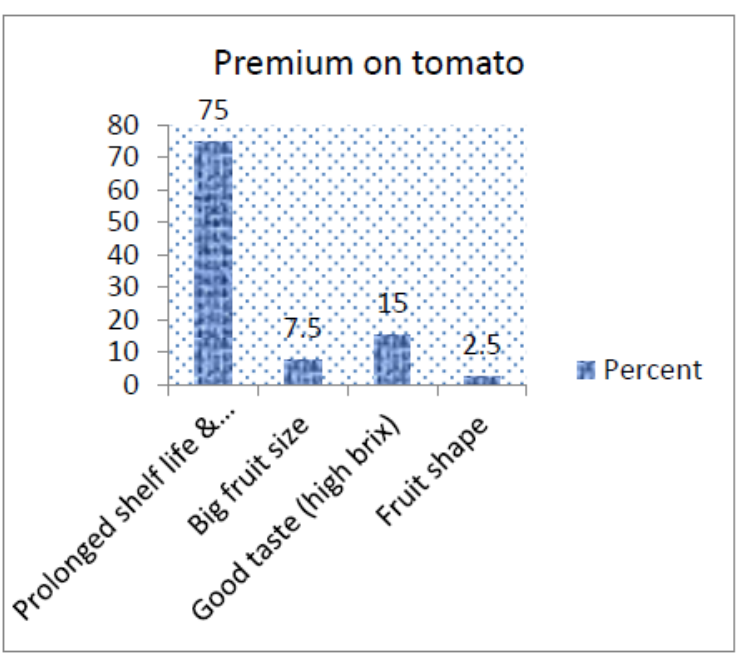

Figure 10 Premium placed by consumers in tomato

Consumers were asked to provide the number of days that they normally keep the tomatoes before deteriorating and from the figure below (figure 11), seventy-five percent of the respondents can store their tomatoes for only 1-4 days. Ten percent and five percent of the respondents can also store their tomatoes in the fresh stage for 5-8 days and 9-12 days respectively.

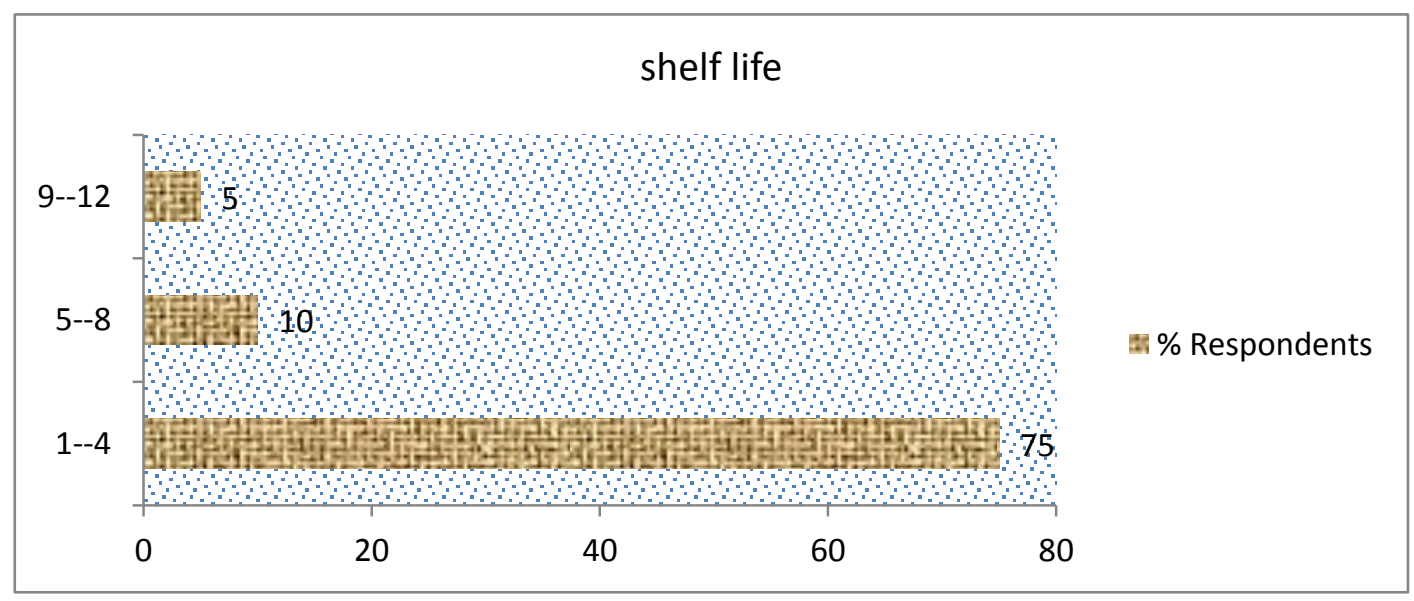

Figure 11. Shelf life of tomato as declared by households

\section{Discussion}

The variation obtained in the variables (questions) used for the Focal Group Discussion (FGD) suggests existence of a high degree of varying perception, knowledge and opinion of tomatoes in Ghana. The level of interest and involvement of participants were very high, indicating that dissimilarities observed may be ascribed to societal background since discussions were held at different communities in different regions. The future of tomato as a food security and an income generation crop was affirmed by the present study. This is fairly declared by the amalgam of stakeholders (farmers, marketers, consumers). Almost all the communities cultivate tomato and rated it as number one vegetable crop produced. The relative ranking position of tomato to other vegetable crops grown in the study areas as mentioned by the respondents confirms the high demand and income generating potential of the crop. This reason is true because according to Wolff (1999) tomato is consumed in almost every household daily. This agrees with Ochieng and Sharman (2004), who also reported that tomato cultivation $+\backslash$ - is a very significant economic activity in Ghana and more profitable than rice, maize, groundnuts, yam, pepper and diary. According to Clottey et al., 2009 as far back as the early 1960, market gardening of tomato had been very important dry season economic activity. In Ghana, production of the crop is an essential profitable activity for smallholder farmers who produce the bulk of the crop. A wide range of areas are suitable 
for tomato production in Ghana. These include the forest, transitional and savanna zones (Norman, 1992). In contemporary years, even though domestic production has increased across the country, the level of production still falls short of domestic demand. As a result, fresh tomatoes are often imported mainly from neighboring Burkina Faso (Horna et al., 2006). This affirms the reason why Ghana imports over 7000 metric tons of fresh tomato per month from neighboring countries, along with 27,000 tons of processed tomato from Europe to meet its high demand (Inusah et al., 2013).

Stakeholders' ideal for postharvest quality traits of tomato included firmness, appearance (colour and shiny surfaces), fruit size, taste and long tomato fruit storage. Their most preferred quality traits are firmness and, prolonged shelf life. This could be due to the fact that firm tomatoes are less prone to damage and tend to have a longer shelf life. For instance, consumers buy tomatoes on the basis of appearance and firmness. Their approval and repeat purchases of the same tomato variety will be contingent upon good flavour quality and perhaps prolonged shelf life. As a matter of fact such tomato varieties are embraced by consumers and sell faster. Tomato is a perishable vegetable fruit and therefore varieties of such crop with increased life span are desirable. Mondal (2000) outlines shelf life as a period of time which starts from harvesting and extends up to the start of rotting of fruits. According to Shahnawaz et al., (2011) high quality tomato fruits have a firm, uniform and shiny colour, good appearance, without signs of mechanical injuries, shrinking and bruises. It is therefore no surprising why the stakeholders' desired for these quality traits. Likewise, for distant transportation, fruits should be firm to avoid physical damage. According to Dhall and Dhatt (2002), the firmness to tomato is provided by skin toughness, flesh thickness and locular area of the fruit. Even though stakeholders have established a positive correlation between firmness and long shelf life, it turns out to be deceitful sometimes. Firmness is an attribute of the tomato fruit when harvested. In other words, it is a general characteristic of the tomato fruit. However, in order to achieve long shelf life in tomatoes we must use specific tomato genes or other approach to inhibit fruit ripening. This implies that a firm tomato may not necessarily have a long shelf life. Dobrzanski and Rybezyski (1998) however, deliberated that firmness is a key characteristics of fruit that are important for quality, harvest, maturity, and shelf- life. According to Bosland (1993) fruit composition at the time of testing (degree of ripeness, size, post-harvest handling and internal temperature) can affect fruit firmness. He further stated that changes in firmness are highly correlated with surface appearance characteristics of tomatoes which associated to colour, shape and sense of feel to firmness.

There were varied responses on farmers' age, education and varieties grown. The age group indicates a mix of young and old people involved in tomato farming. The large number of young people involved in tomato production is an enthusiastic progress since the youth are noted to abandon farming in quest of other businesses in the cities. More young people can be encouraged to pursue tomato production to reduce the unemployment rate in the country and help to address the negative trend of the youth forsaking agriculture in general. The educational status of the farmers who attained up to primary/JHS/Middle school was more than half of the entire respondents indicating dominance by people with basic level education. This can thus be implied that respondents' level of education is satisfactory to offer them with the necessary professional expertise that will assist them to successfully accomplish their farm enterprise. This finding confirms with Seidu (2008), who stressed that education enables farmers to understand the social and economic conditions governing their farming activities and thereby increasing their output and also in confirmation with findings of Asante et al., (2013). He further emphasized that production or farming experience is positively related to technical efficiency. This implies that accumulated experiences can influence farmers to mobilize and use labour effectively coupled with appropriate record keeping. Farmers who are better educated are generally more open to innovative ideas and new technologies that promote technical change (Lapar \& Ehui, 2003). The male dominance of tomato production implies the laborious nature of tomato farming operations right from nursing to harvest which their female counterparts cannot easily undertake.

Although respondents gave diverse shelf life of their tomato fruits, majority of the respondents could store their tomato fruits for few days (less than a week). According to Kader (1992), the high moisture content of tomatoes (above 95\%) and its soft outer covering predisposes it to microbial spoilage and short shelf life, thus leading to high annual postharvest losses (PHL) (20-50\%) of the crop. Fresh tomatoes are more traditional and culturally accepted in food application and as such farmers will want to employ various ways to increase the shelf life of their tomatoes. This is in agreement with Rozin and Vollmecke (1986) who indicated that cultural factors influence food choices because of the differences in both perception and preference. Respondents argue their displeasure in the reduction of their quantity and quality of produce therefore affecting their profit margin. As tomatoes are usually harvested over a limited period of time, it is thus required to provide storage for the fruits in order to regulate marketing and preserve high quality. As a matter of fact farmers employ temporary measures to 
offset the poor storage life. According to Engindeniz (2007) because of the highly perishable nature of tomato, farmers attempt to store them in a variety of traditional structures which are greatly inappropriate thus resulting in substantial losses. The majority of respondents who harvest at breaker stage has confidence that by the time it gets to the buyer it would be in good condition and stays for some time prior to deterioration. Others who applied fungicides few days before harvesting also rely on the fungicides to make the tomato skin tough and thus prolonging the storage life. A lot of problems related to post-harvest life of tomato are associated with microbial and fungal deterioration of fruit. A number of fungal species have been described as contributory agents of tomato decay during storage (Singh et al., 2016).

Despite the seeming different opinions and thoughts of poor shelf life, respondents perceived to genetic or hereditary suggesting that they have certain knowledge of the characteristic nature of tomato. According to Norman (1992) tomato fruit contain about $93 \%$ moisture and the rest being solids. However, certain tomato varieties are able to delay or slow down ethylene production responsible for ripening thus ensuring prolonged shelf life. Majority of the respondents who were of the view that lack of ready market deepens the problem of poor shelf life is an absolute fact. Robinson and Shashi (2010) attest to the problem of unreliable market when they conducted a research on marketing; the case of tomato in the Upper East region of Ghana. This was also confirmed by Farida and Fariya (2014) who analysed the production and marketing of tomato and indicated lack of reliable market as important challenge in the tomato industry. They further mentioned that for production to be lucrative and serve as a motivation there should be ready market and a good price for the output. This is often impeded by the strong competition between imported and local tomato which somewhat regularly does not favor local production. Moreover prices of fresh tomatoes are unpredictable. Day-to-day prices may fluctuate due to transportation problems or adverse weather conditions in both supply and demand regions. According to Caballero (2008) profitability of tomato is not only determined by production cost and yield but also price. Prices determine income and define income levels for agricultural producers as well as their incentives to invest in new technology.

In general the distribution of agricultural food commodities in Ghana is controlled by women. It was therefore not surprising to see a predominance of the female market players in their early thirties to fifties. With nearly half of the market players having acquired more than 11 years in the tomato business was adequate enough to elicit palpable information on their preferences, perceptions and knowledge about postharvest quality traits of tomato. This further explains why a great number of the market players were aware of the varieties they sell to their clients or customers and could distinguish local from exotic varieties of tomato. The tomato market is one of the better organized sectors where each player has a well-defined function at specific stages in the marketing chain. In the tomato marketing chain it is easy to identify players in the categories of market queens, wholesalers and retailers. The trade is often undertaken by an association of women traders who are led by "tomato queen mothers" from the Southern parts of the Ghana. These queen mothers play protective roles in the markets as well as ensuring the welfare of their members. Buying at the farm gate is done by these queen mothers who sell to wholesale buyers and retailers. Other service workers include women who sort and package the tomatoes, drivers and loading boys, as well as middle men who bargain for the produce. Traders and middlemen have accumulated marketing strategies that enable them to bargain for lesser prices at farm gates. The goods are then sold at high prices in towns and city markets, benefiting the trader or the middleman rather than the farmer.

Market players desire firmness as an important quality trait for grading their tomatoes. This is because the fruit quality as it is directly related to fruit development, maturity; ripening and storage potential correlate with firmness. It is therefore not unimagined to hear market players classifying firmness as an important benchmark for grading their tomatoes. This is buttressed by Dobrzanski and Rybezyski (1998) who specified firmness as a key characteristic of tomato fruit essential for value. Even though Sargent and Moretti (2002) revealed that high quality fruits have firm appearance, Banaras et al., (1988) added that firmness of tomato fruits depends on the cultivar types and their morphological characteristics. Majority of the market players especially the retailers who experienced losing their tomatoes as a result of poor storage and absence of ready market resort to reducing the price of their tomatoes so as to clear them off. Similarly owing to lack of processing and storage facilities, farmers are compelled to sell at low prices rather than lose the entire product. The highly perishable nature of tomatoes therefore presents a market threat in the tomato industry. Traders especially retailers who faced this dilemma often compromise their moral values in order to make a profit. In many instances, they sell on credits to customers based on pure trust with the hope that they will be sincere enough to pay when they get the money but this drill has often resulted in defaults (Evers, 1994).

Tomato utilization and consumption varied among the respondents (consumers). Whereas tomatoes are used in different forms chiefly for soup and stew, consumption rate is daily according to majority of the respondents 
interviewed. This confirms Wolff (1999) who indicated that tomato is consumed in almost every household daily. It is estimated that Ghana produces over 300,000 MT of tomatoes and $90 \%$ of the production is consumed locally. It also imports over 78,000 tons of tomato paste and puree per year to meet the ever increasing demand of the crop. Most of the consumers also desire firmness including freshness and ripeness for a good quality tomato. In another instance majority of the respondents (consumers) put premium on prolonged shelf life and firmness. This suggests that respondents have high preference for tomatoes with good firmness and extended shelf life, justifying the need for the present study.

According to Barret et al., (1994) the variation of shelf life in tomatoes is as a result of the changes in fruit ripening. A tomato with a good shelf life will allow consumers to buy more of such varieties and also reduce the number of times in going to the market to purchase tomato. Hence any time they visit the market they will buy enough of such tomato varieties with guarantee that the shelf life is good. The shelf life of tomatoes depends on the date picked or purchase since there is usually no sell by date, use by date or best before date attached anywhere to tomatoes. Fresh tomatoes will begin to get soft and then may leak liquid when they are going bad. They may also begin to mold, at which point they have gone bad and you will want to throw them out. A typical example is the loss of firm texture which is related to the structure and cell wall composition, mainly pectic fraction which, when degraded, causes softening of the tomato fruit. Another problem experience with having fresh fruit on the counter is the sudden presence of fruit flies.

\section{Conclusion}

The study acknowledged and established the potential of tomato as a food security and an income generating crop in Ghana. It identified and interrogated key tomato stakeholders from four agroecological zones representing major tomato growing areas in Ghana. It also revealed stakeholders' desire and plea for firmness and extended shelf life of tomato fruits in Ghana. Consequently, the survey validates the need to regulate tomato breeding goals to develop high yielding tomatoes with improved fruit quality and prolonged shelf life. It is imperative that breeding programmes of tomatoes should be tailored to accommodate particular community desires and preferences.

\section{Acknowledgements}

The authors are indebted to Syngenta for providing financial support for their tomato research work. We thank Dr. Collins Kwabena Osei of Institute of Distance Learning (IDL), Kwame Nkrumah University of Science and Technology (KNUST), Kumasi, Ghana, Dr. Ernest Berfi and Mrs. Harriet Dwamena, all of CSIR-Crops Research Institute (CSIR-CRI), Kumasi, Ghana for their pre-paper reviews.

\section{Reference}

Asante, B. O., Osei, M. K., Dankyi, A. A., Berchie, J. N., Mochiah, M. B., Lamptey J. N. L., \& Bolfrey-Arku, G. (2013). Producer Characteristics and Determinants of Technical Efficiency of Tomato based production systems in Ghana. Journal of Development and Agricultural Economics, 5(3), 92-103.

Banaras, M., Lownds, N. K., \& Bosland, P. W. (1988). Relationship of physical properties to postharvest water loss in pepper fruits (Capsicum annuum L.). Pak. J. Bot., 26(2), 321-326.

Barret Reina, L. dei C., Chitarra, M. I., \& Chitarra, A. B. (1994). Choque a frio a atmosfera modificada no aumento de vida pós-colheita de tomates: coloração e textura. Ciência e Tecnologia de Alimentos, Campinas, 14(1), 14-126.

Banziger, M., \& Cooper, M. (2001). Breeding for low input conditions and consequences for participatory plant breeding: Examples from tropical maize and wheat. Euphytica, 122, 503-519.

Beckles, D. M. (2012). Factors affecting the postharvest soluble solids and sugar content of tomato (Solanum lycopersicum L.) fruit. Postharvest Biology and Technology, 63(1), 129-140.

Bosland, P. W, (1993). Breeding for quality Capsicum. Capsicum News, 12, 25-31

Caballero, P. (2008). Price trends in greenhouse tomato and pepper and choice of adoptable technology. Spanish Journal of Agricultural Research, 6(3), 320-332.

Clottey, V. A., Karbo, N., \& Gyasi, K. O. (2009). The Tomato Industry in Northern Ghana: Production Constraints and Strategies to improve Competitiveness. Afric. J. Food, Agric., Nutr. And Dev., 9(6), $1436-1451$

David, M., \& Sutton, C. D. (2004). Social Research: the basics, Sage Publications, London

Derera, J., Tongoona, P., Langyintuo, A., Laing, M. D., \& Vivek, B. (2006). Farmer perception on maize 
cultivars in the marginal eastern belt of Zimbabwe and their implications for breeding. African Crop Science Journal, 14, 1-5.

Dhall, R. K., \& Dhatt, A. S. (2002), Horticulture have quality will export. Retrieved from http://www.tribuneindia.com/2002/20020819/agro.htm

Dobrzanski, B., \& Rybezynski, R. (1998). A simple device for accurate strain measurement on apple fruits. Acta Horticulture, 421, 223-230.

Engindeniz, S. (2007). Economic analysis of processing tomato growing, West Turkey. Spanish Journal of Agriculture Research, 5(1), 7-15.

Etzkorn, B. (2011). Data Normalization and Standardization. Retrieved from htt:>//www.Benetzkorn.com/2011/11/Data Nomalization-and-Standardization. Retrieved on 19/2/2018

Evers, H. D. (1994). Social and Cultural Dimensions of Market Expansion. Unpublished Paper of Sociology of the Development Research Centre, University of Bielefeld

Farida, A., \& Fariya, A. (2014). Analysis of Production and Marketing Constraints of Tomato among Rural Farmers in Talensi Nabdam District of Upper East Region of Ghana. IJASRT in EESs, 4(1).

Field, A. (2000). Discovering statistics using SPSS (1st ed.). London: Sage Publications Ltd 2000, ISBN 978-1-84787-906-6

Field, A. P. (2005). Discovering statistics using SPSS (2nd ed.). London: Sage Publications Ltd 2005, ISBN $0-7619-4452-4$

Gasura, E., Mashingaidze, A. B., \& Mukasa, S. B. (2008). Genetic variability for tuber yield, quality, and virus disease complex in Uganda sweetpotato germplasm African Crop Science Journal, 16, 147-160.

Gibson, R. W., Byamukama, E., Mpembe, I., Kayongo, J., \& Mwanga, R. O. M. (2007). Working with farmer groups in Uganda to develop new sweet potato cultivars: Decentralization and building on traditional approaches. Euphytica, 159, 217-228.

Horna, D., Zabel, P., \& Lindout, P. (2006). Assessing the potential economic impact of genetically modified crops in Ghana: Tomato, garden egg, cabbage and cassava. Program for Biosafety Systems report. October, 2006.

Inusah, I. Y., Baba, J. Y., \& Michael, M. M. (2013). The Tomato Industry in Ghana-Fundamental challenges, surmounting strategies and perspectives-A review. International Journal of Current Research, 5(12), $4102-4107$.

Kader, A. A. (1992). Postharvest Technology of Horticultural Crops. Second edition, Univ. Calif., Div. of Agr. and Nat. Resources, Publ., 3311, 296.

Kumar, R. (1999). Research Methodology; a step-by-step guide for beginners. Third edition, SAGE publications ltd. Pp 1-366 www.sage.publication.com

Lapar, M. L. A., \& Ehui, S. (2003). Adoption of dual-purpose forages: some policy implications. Trop. Grasslands, 37, 284-291

Lewin, C. (2005). Elementary quantitative methods. In B. Somekh \& C. Lewin (Eds.), Research methods in the social sciences (pp. 215-225). London: Sage

Mondal, M. F. (2000). Production and Storage of Fruits (in Bangla). BAU Campus, Mymensingh-2202. Pp-312.

Norman, J. C. (1992). Tropical vegetable crops. Arthur, H. Stockwell Ltd, Ilfracombe, Great Britain. Pp.52-77.

Ochieng, C., \& Sharman, T. (2004). Trade Traps: Why the Proposed Economic Partnership Agreements Pose Threat to Africa's Development, London: www.actionaid.org

Oko-Ibom, G. O., \& Asiegbu, J. E. (2007). Aspects of tomato fruit quality as influenced by cultivar and scheme of fertilizer application. Journal of Agriculture, Food, Environment and Extension, 6(1), 71-81.

Robinson, E. J. Z., \& Shashi, K. L. (2010). The Case of Tomato in Ghana: Marketing. Working Paper \#20. Accra, Ghana: International Food Program.

Rozin, P., \& Vollmecke, T. A. (1986). Food Likes and Dislikes. Ann. Rev. Nutr., 6, 433-56

Sargent, S., \& Moretti, C. (2002). Tomato. In: Gross, K. Wang, C. and Saltveit, M. (eds.). The Commercial Storage of Fruits, Vegetables, and Florist and Nursery Stocks. United States Department of Agriculture Handbook 66. 
Seidu, A. (2008). Technical Efficiency of Rice Farmers in Northern Ghana. African Economic Research Consortium, Research Paper, 178.

Shahnawaz, M., Sheikh, S. A., Soomro, A. H., Panhwar, A. A., \& Khaskheli, S. G. (2012). Quality characteristics of tomatoes (Lycopersicon esculentum) stored in various wrapping materials. Afr J Food Sci Tech., 3, 123-128

Singh, A., Singh, D., \& Singh, R. (2016). Shelf life extension of tomatoes by gamma radiation. Radiation Science and Technology, 2(2), 17-24

SPSS (2017). Social scientist statistical package for windows release 16.0. SPSS inc. 1989-2007.

Sugri, I., Nutsugah, S. K., Wiredu, A. N., Johnson, P. N. T., \& Aduguba, D. (2012). Kendall's concordance analysis of sensory descriptors influencing consumer preference for sweetpotatoes in Ghana. American Journal of Food Technology, 7, 142-150.

Toomey, G. (1999). Farmer as researchers: The rise of participatory Plant breeding. International development Research centre, Ottawa, Canada. IDRC Online Archive. Available at: http://www.idrc.Ca/ev_en.php? ID? $\mathrm{ID}=5559 \& \mathrm{ID} 2=\mathrm{DO} \_$TOPIC.

VSN International (2011). Genstat for Windows 14th Edition. VSN International, Hemel Hempstead, UK. Web page: GenStat.co.uk

Wolff, H. (1999). Economics of tomato production with special reference to aspects of plant protection: A case study of two tomato production systems in Brong-Ahafo region, Ghana. Prepared for Ghanaian-German Project for Integrated Crop Protection. GTZ: Eschborn.

\section{Copyrights}

Copyright for this article is retained by the author(s), with first publication rights granted to the journal.

This is an open-access article distributed under the terms and conditions of the Creative Commons Attribution license (http://creativecommons.org/licenses/by/3.0/). 